TURIZAM

Volume 16 , Issue 2

65-77 (2012)

\title{
Events as a Framework for Tourist Destination Branding - Case Studies of Two Cultural Events in Croatia
}

\author{
Klara Trošt*, Sara Klarić*, Marinela Dropulić Ružić* \\ Received: January 2012 | Accepted: May 2012
}

\begin{abstract}
Events have become an increasingly significant component of destination branding. Many destinations throughout the world have developed events portfolios as a strategic initiative to attract tourists and to reinforce their brand. In this paper, the focus of research will be on tourist destination branding by means of events.

The relationship between events and destination branding is examined through six phases of the process of building a destination brand identity with the use of events. When it comes to destination branding, a need for an analysis of strategic documents of destination development imposes because event tourism strategies help destinations plan how to use events in a tourism role.

The purpose of this study is to examine which factors are of the top priorities when using events as a marketing approach. The method of case study will be used, by which two cultural events which take place in the Republic of Croatia will be analyzed, namely, "Špancirfest" in Varaždin and "Trka na prstenac" in Barban. Varaždin and Barban are on different levels in their branding work. The different sizes and locations of the destinations naturally affect the operating procedures.

This article may be of interest to destination marketers and event organizers, especially in developing destinations which intend to differentiate themselves from the competitive market.
\end{abstract}

Key words: tourist destination, events, destination branding, Varaždin, Barban

\section{Introduction}

In tourist destination offer there are an increased number of special events whose creation and staging is conditioned by strategic reasons of an, above all, economic nature (Getz, 2007). However, the role of events in a destination tourist offer is also significant due to their tourist, social and cultural functions (Getz, 2008), as well as their role in local and regional development (Wood, 2005; O’Sullivan, Pickernell \& Senyard, 2009). By events, local culture, tradition and customs are assessed (Hong, 20IO), participants' entertainment and recreation

\footnotetext{
* M.Econ., Institute of Agriculture and Tourism, Tourism Department, K. Huguesa 8, 52440 Poreč, Croatia, T. 0038552408 326, F. 0038552431 659; klarat@iptpo.hr; klaric.sara@gmail.com; marinela@iptpo.hr
} 
are ensured, as well as social cohesion and cultural and social progress (Fredline \& Faulkner, 2000; Derrett, 2000), which represents social and cultural event functions. Tourist event functions are manifested through broadening of the tourist destination market (Priporas, 2005), extension of tourist stays at a destination and facilitation of better promotion of a destination (Richards \& Wilson, 20O2; McDonnell \& Gebhardt, 20O2), attraction of investment to a destination (Schulenkorf, 2OIO), as an element of attraction and animation in a destination (Derret, 20O2), as well as the building of a destination brand (Jago, Chalip, Brown, Mules \& Ali, 2OO2; Xing \& Chalip, 2006). In this paper, the research focus is in the branding itself of tourist destinations by means of events. The purpose of this study is to examine which factors are of the top priorities when using events as a marketing approach. Specifically, its aims are to:

- Analyse the relationship between events and destination branding through six phases of the process of building a destination's brand with the use of events;

- Analyse cultural events "Špancirfest" in Varaždin and "Trka na prstenac" in Barban through case study;

- Analyse the event offer in the tourist destinations Barban and Varaždin according to the number and type of events, as well as their duration;

- Analyse the process and impacts of the branding of the tourist destinations Barban and Varaždin;

- Analyse the role of events as a marketing tool in the branding of the tourist destinations Barban and Varaždin;

- Determine strategic documents for event development and who is responsible for their preparation and implementation;

This paper contributes a review of the background literature, examining the relationship between events and destination branding, and analysing by case study two cultural events which take place in the Republic of Croatia, namely "Špancirfest” in Varaždin and "Trka na prstenac" in Barban. Varaždin and Barban are at different levels in their branding work. The different sizes and locations of the destinations naturally affect the operating procedures.

\section{Theoretical Background}

\section{Event marketing as a part of event management}

Event management encompasses the planning and production of all types of events, including meetings and conventions, exhibitions and other cultural celebrations, sports competitions, entertainment shows, private functions and numerous other special events (Getz, 2005). According to Bowdin et al. (2006, p.I5), "events are a special rite, presentation, performance or celebration which is continuously planned and created in order to mark special events and/or to achieve special social, cultural or corporate aims and targets".

Event marketing forms an integral part of the event management, which deals with various aspects of organization and event management. The process of event organization is made up of a series of steps, among which is also marketing. According to O'Toole (2005, p. 55; according to Allen, 20O2) „marketing is that function of event management that can keep in touch with the event's participants and visitors (consumers), read their needs and motivations, develop products that meet these needs, and build a communication program which expresses the event's purpose and objectives." 
According to O'Toole (2005, p. 55) „events and festivals share many of the characteristics of service industries as they require a different marketing process to that of manufactured goods." These characteristics are (O’Toole, 2005, p. 56; according to Shone, 200I):

- Inseparability - the consumption and production of the product take place simultaneously;

- Perishability - the event occurs at one point in time. If the event does not go ahead, the marketing expenditure is lost. It is difficult or impossible to resell the event, as can be the case with manufactured products;

- Intangibility - the experience of the event by the customer happens at the event itself. It is unique and cannot be experienced before the event. Intangibility also means that event experience is difficult to measure;

- Heterogeneity - each customer of the event may have a different experience.

\section{Destination branding}

Although the concept of branding has been applied extensively to products and services, the notion of branding has only recently started to expand into tourist destinations and became apparent as a topic of examination in the late I99O's (Tasci \& Kozak, 2006; Pike, 2004; Wagner \& Peters, 2009). Due to the fierce competition in the international tourist market and an increasing number of destinations with a developed and quality tourist offer, a relatively new trend among destination marketing organizations (DMOs) is to turn their destination into a brand.

The simplest definition of destination branding was provided by Morrison \& Anderson (20O2, p.I7), according to whom it is "the process used to develop a unique identity and personality that is different from all competitive destinations". Destination branding has been also defined as "a set of marketing activities that I) support the creation of a name, symbol, logo, word mark or other graphic that readily identifies and differentiates a destination; that 2) consistently convey the expectation of a memorable travel experience that is uniquely associated with the destination; that 3) serve to consolidate and reinforce the emotional connection between the visitor and the destination; and that 4) reduce consumer search costs and perceived risk" (Blain, Levy \& Ritchie, 2005, p. 337). Collectively, these activities serve to create a destination image that positively influences consumer destination choice.

In Figure I, it is evident that, by adapting product brands to destination brands, destination brands can therefore perform the role of reduction for the tourist, in that it can aid in the identification of specific products and services and in turn reduce search costs, perceived risk and provide psychological reward.. For the product/service provider's destination brands perform the role of facilitation, that is, they ease some of the tasks carries out by these providers thus facilitating repeat purchase and enhancing financial performance (Berthon, Hulbert \& Pitt, I999). The process of branding adjusted to tourist destinations consists of seven concurrent phases, 7A (Baker, 2007; Križman-Pavlović, 2008):

- Assessment and Audit - assessment of the current market position of a destination as a brand is essential in order to objectively determine its strengths and weaknesses;

- Analysis and Advantage - analysis of information collected during the previous phase is conducted, which will be used to create a realistic picture of the dimensions of a tourist destination as a brand and to determine the activities necessary to remove the shortcomings identified; 
- Architecture and Alignment - links between a tourist destination as a brand with localities, parts and experiences within its limits, i.e. with so-called sub-brands are examined;

- Articulate - after the brand platform and tourist destination promise have been defined, design of the verbal and visual system of identity of a tourist destination as a brand follows;

- Activation - instruments of an integrated marketing communication, by which the brand will be "brought to life", in order to instigate the consumers' desired answers, are determined;

- Adoption and Attitudes - the aim is to encourage understanding, adoption and consistent brand application with all tourist destination internal participants, whose behavior in accordance with the brand can lead to a bigger loyalty of consumers and a tourist destination with a powerful reputation and respect;

- Action and Afterward - long-term brand vitality depends on how the organization for tourist destination management handles the following activities: leading the brand, managing the brand, conveying the brand message, experience management and monitoring and evaluation.

Events have become an increasingly significant component of destination branding. Many destinations throughout the world have developed events portfolios as a strategic initiative to attract tourists and to reinforce their brand. Due to this, the relationship between events and destination branding will be analyzed further in this paper.

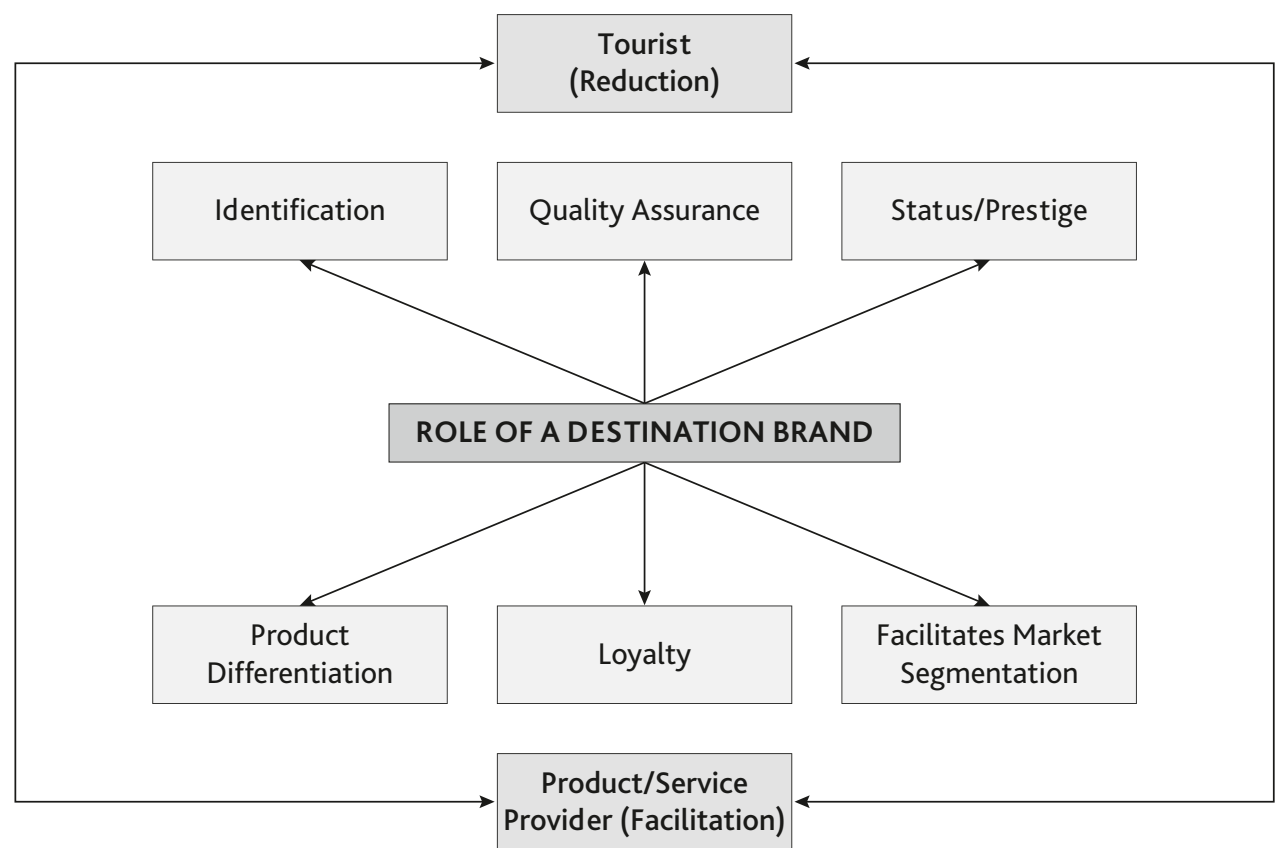

Figure 1. Role of a Destination Brand for the Tourist and Product/Service Provider Source: Quinlan, T., A Stakeholder Approach to the Branding of Urban Tourism Destinations, Master's Thesis, Waterford Institute of Technology, 2008, p. 34 (adapted from Berthon, Hulbert \& Pitt, 1999) 


\section{Using events as tools to create a destination's brand}

A relatively new strategy among destinations is to use events in strategically building the brand (Getz, 2005). Events are part of the attraction of a destination and as such should be included in the integrated marketing campaign for the destination and incorporated into a destination's branding strategy (Jago, Chalip, Brown, Mules \& Ali, 2003). This implies the need to evaluate the contribution of an event not just in terms of the direct financial contribution that it generates but also in terms of its consistency with the destination brand values.

Events with well-established brands can be used to enhance the brand identity of the destination. This may be referred to as co-branding, which Chalip \& Costa (2005) describe as the practice of pairing the event's brand with the brand of the destination. The desire is thus that characteristics of the event's brand will transfer to the destination's brand, and vice versa (Xing \& Chalip, 2006). According to Jayaswal (2009, p. 23) "the key to a successful destination-event co-branding strategy is to identify the associating network of competitive destinations and then host an event that can reinforce, change or add desirable associations".

Since the tourism destination is composed by a set of multifaceted experiences and attractions marketed under one brand, Marzano \& Scott (2006, p. I99) emphasize that "the challenge for events planners and managers is to consistently fit the events into the interrelationships among the elements of the marketing mix and therefore enhancing the destination brand equity". There is a no natural or automatic harmony or synergy between events and the other products offered in a destination (Fyall \& Garrod, 2005). Therefore conflict generated by the different interests and the diverging objectives of tourism stakeholders might be enhanced by a negative evaluation of the media coverage or publicity of the event (Carlsen, Getz \& Soutar, 2000) that carries a negative impact on the tourism common good of the destination brand equity.

Johansson (2007) has developed a model that illustrates the steps followed when building a destination brand identity with the use of events. The process is demonstrated in Figure 2 and it's divided into six phases (Johansson, 2007, p. 66-72):

- Phase I - the process starts with the planning and coordination phase. At this stage the relevant stakeholders at the destination should together discuss the roles of each entity and the vision for the destination;

- Phase 2 - after the research phase, the process enters the stage when the objectives and goals should be determined;

- Phase 3 - this phase represents the use of events when shaping the brand identity;

- Phase 4 - this stage is the entry to the circular process and signifies how the brand identity is established by linking the events to the brand essence, core values and personality of the destination.

- Phase $\mathbf{5}$ - the next stage represents the phase of bringing the identity to life with visual and verbal identity.

- Phase 6 - the last phase of the process is that of event evaluation

The pyramid in the middle of phase 4-6 illustrates the importance of considering the whole portfolio of events, since a single event is considered to have only a passing effect on the destination brand, and that synergy between all events at a destination is vital if the objective is for events to generate a significant effect on the destination brand (Johansson, 2007).

Esu \& Mbaze-Arrey (2009, p. I83) claim that "when an event is properly branded, it has the potentials of contributing to the host destination as a feature (attraction) to make the destination unique in nature and even popular to prospective visitors". 

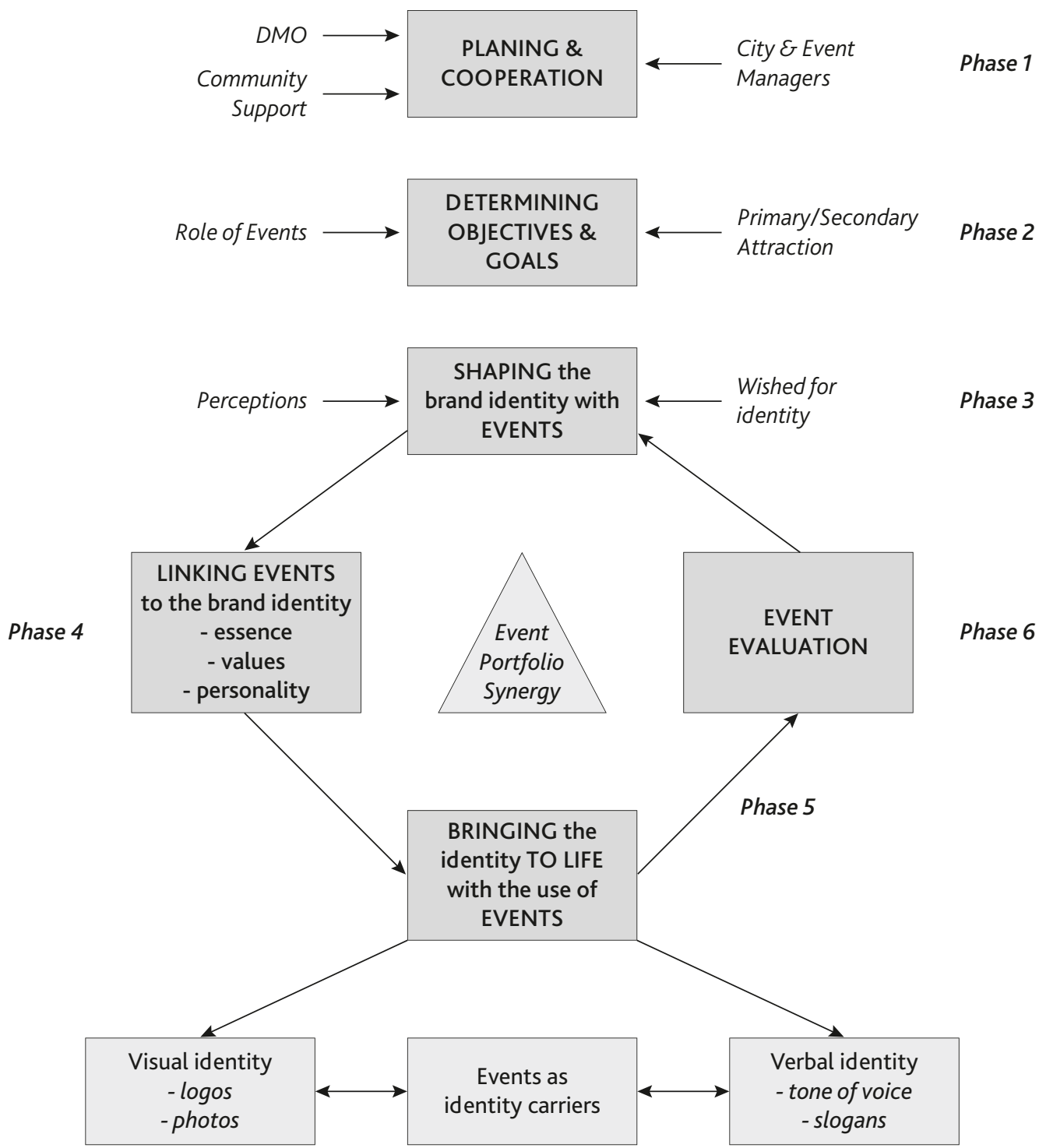

Figure 2. The process of building a destination brand identity with the use of events

Source: Johansson, J., Working with Events to build a Destination Brand Identity - the DMO Perspective, Master's Thesis, School of Business, Economics and Law - Göteborg University, 2007, p. 66 


\section{Case studies: Špancirfest and Trka na prstenac - What are the Differences?}

\section{Cultural events comparison}

\begin{tabular}{|c|c|c|}
\hline Name & TRKA NA PRSTENAC & ŠPANCIRFEST \\
\hline Type of event & Knight game & Street festival \\
\hline Organizer & $\begin{array}{l}\text { Association Trka na prstenac, Municipality } \\
\text { of Barban and Tourist Organization Barban, } \\
\text { under the auspices of the County of Istria. }\end{array}$ & $\begin{array}{l}\text { Tourist organization of the town of Varaždin; } \\
\text { the festival is financed exclusively thanks to } \\
\text { sponsorship contracts and donated funds }\end{array}$ \\
\hline Event history & $\begin{array}{l}\text { First records of Trka na prstenac date back } \\
\text { from 1696, when the Loredan family, then } \\
\text { the owners of the whole of Barban, organized } \\
\text { a knight game in order to attract as many } \\
\text { visitors as possible during fair performances. } \\
\text { The Trka was revived in } 1976 \text { and has been } \\
\text { held continually, to date. }\end{array}$ & Held since 1999 \\
\hline Event held & in August & In August, end of month \\
\hline Event venue & Town of Barban in the County of Istria & $\begin{array}{l}\text { streets and squares of the town of Varaždin } \\
\text { in the County of Varaždin }\end{array}$ \\
\hline Event contents & $\begin{array}{l}\text { In the four days of this event, various con- } \\
\text { tents are represented, from eno-gastronom- } \\
\text { ic, through concerts, other entertainment } \\
\text { programmes, to the event focal point, the } \\
\text { sports competition Trka na prstenac. }\end{array}$ & $\begin{array}{l}\text { Shows, children's programmes, comedies, } \\
\text { concerts of classical, ethno, rock, blues and } \\
\text { jazz music, as well as various performances } \\
\text { by street artists and musicians, acrobats, jon- } \\
\text { gleurs and puppet shows. During the ten days } \\
\text { of the festival, some } 300 \text { sub-programmes } \\
\text { are held. }\end{array}$ \\
\hline Visitor statistics & $\begin{array}{l}\text { Over } 10,000 \text { visitors attended the focal } \\
\text { event point, Trka na prstenac, in } 2011 .\end{array}$ & $\begin{array}{l}\text { In the } 12 \text { years of the festival, } 2 \text { million } \\
\text { visitors attended Špancirfest and } 11,000 \\
\text { performers appeared on five stages in the } \\
\text { squares and streets of the baroque town } \\
\text { centre. In } 2011,200,000 \text { visitors attended } \\
\text { this event. }\end{array}$ \\
\hline $\begin{array}{l}\text { Awards and cer- } \\
\text { tificates: }\end{array}$ & I & $\begin{array}{l}\text { Špancirfest received numerous awards, } \\
\text { among which was the award Superbrand for } \\
\text { the year } 2009 .\end{array}$ \\
\hline $\begin{array}{l}\text { Event destination } \\
\text { specific qualities }\end{array}$ & $\begin{array}{l}\text { Barban is characterized by tradition, cultural } \\
\text { heritage and hospitality of hosts in farm } \\
\text { households. }\end{array}$ & $\begin{array}{l}\text { Varaždin represents an exciting blend of } \\
\text { traditional and contemporary qualities }\end{array}$ \\
\hline
\end{tabular}

\section{Methodology and analysis}

Paper's research is of an exploratory and descriptive character with the aim to determine the most important impacts in the process of using of events as a marketing tool. Given that the intention is to understand and explain how events influence destination branding, in this paper the methodology of case study was chosen, which will in the end, result in a comparative analysis. Yin (2003, p.I) stresses that "generally speaking, case studies are a good method of making a statement when answers are required to the questions "how" and "why", when a researcher has a negligible influence on events even when a current phenomenon within life context is in the focus". Furthermore, the same author (p. 38) warns that the 
most frequent remarks which are associated with the use of the case study method, concern "impossibility of generalization of one case in relation to others". In this paper, an attempt was made to avoid the trap of generalization and its intention is to determine the differences among cultural events in different contexts. Therefore, the starting point in the case study preparation consists of the selection of cultural events which differ by the venue and context of staging. Different geographical venue location is considered to be an important criterion in the selection of these destinations, as it is supposed that smaller destinations, regardless of their geographical locations or their tourist market position, due to the lack of resources and financial support, experience difficulties in using events in the process of branding.

The research framework is made up of the following research questions I) What level of development is branding of Barban and Varaždin at? 2) What are the impacts of branding of Barban and Varaždin? 3) What is the relationship between events and tourist destinations in selected destinations? 4) Apart from Špancirfest and Trka na prstenac, how many and which type of events are organized in Varaždin and Barban? 5) When are they held? 6) Are there any strategic documents pertinent to the development of events in the aforementioned destinations?

The structured questionnaire with I6 questions is divided into three parts and is thematically structured, starting from general, to specific. The first part of the questionnaire relates to the questions about tourist destination branding in general, where the surveyees are asked to briefly describe: I) the started process of branding of the destination where they work, 2) branding impacts, 3) whether events are used as a marketing tool in the process of branding and 4) which factors influence the most the efficient use of events in the process of destination branding. The second part of the questionnaire is directed to obtaining specific information about branding of the events Špancirfest and Trka na prstenac, while the last part related to the strategic documents of event development in a destination, namely to their preparation and implementation both at the level of the entire destination and individual events. The questions in the structured questionnaire are open-ended in order to stimulate the surveyees to expose the largest possible number of details and explanations. The research was conducted in October 20 II by sending the prepared questionnaires to the email addresses of the two directors of tourist organizations of Barban and Varaždin. This was preceded by telephone contact with them in order to inform the surveyees about the research goals and to ask them to contribute to this research by their participation.

\section{Results}

An attempt was made to additionally ensure the reliability and credibility of the obtained data through a check of available website documentation. The intention was to collect all the data relative to the event structure, taking into consideration the criteria of: I) division by types and 2) time of staging.

The results of research of the event calendar in the tourist destination of Barban, which is situated in the Croatian coastline region in the county of Istria, show that cultural events (7I\%) are also the most numerous. Cultural events include festivals, religious events, carnivals, folk celebrations and various local events (Getz, 2008). They are followed by art events with $22 \%$ and sports events with $7 \%$. The analysis of event calendar according to the time scope shows that the largest numbers of events are staged during the months of July and August. 
The research results for tourist destination Varaždin show that in the structure of events the most important part is made up of art events with $78 \%$, followed by cultural events with $9 \%$, sports events with $8 \%$, educational and scientific events with $4 \%$ and business events with $\mathrm{I} \%$. The analysis of events according to the time scope indicates that events in Varaždin, which is situated in continental Croatia, are equally spread throughout the whole year, with a slight decline in the number of events during the months of November and December. Art events, as the most important ones, are mostly held during the months of May and June.

It was determined by interview that participants' subjective impressions in the research relating to the concept and process of destination branding fully correspond to the opinions of the world experts, who claim that branding has become one of the most powerful tools in marketing strategy (Caldwell \& Freire, 2004). Namely, destinations which do not understand do not articulate or do not apply the concept of brand as a focused marketing, but also a managerial tool, will lag behind the competition in the international tourist market (Telišman-Košuta, 2OII).

By the analysis of the activities to date pertinent to the process of branding of selected tourist destinations, it was established that, in the past several years, numerous activities associated with the possible brands of Barbanština (horses, wine, olives, figs, mushrooms, honey and folklore), were launched. However, the process of branding in the destination of Barban is still at the beginning and only Trka na prstenac can, for now, be identified as a Barban brand. On the other hand, Varaždin was defined a destination brand in all segments by an outside agency and the Town of Varaždin's Tourist Organization derives all their activities from the defined brand.

As for the impacts of the destination branding, for Barban, a creation of recognisability is identified and for Varaždin, a rising trend of visits and tourist expenditure by the target group, which confirms that a differential and positive destination perception has been created. Apart from the already mentioned impacts, it is certainly necessary to identify some more which emanate from successful destination branding and they are generally evident in the increase in foreign investment, preservation and promotion of own identity and tradition, as well as in the strengthening of quality of life and destination image.

Through the interview, it was furthermore established that both directors of the Tourist Organizations realized the importance of the roles of events in the offer and in the process of tourist destination branding, which corresponds to the research by the authors Jago, Chalip, Brown, Mules \& Ali (2003) and this is that event marketers, as well as tourism stakeholders in Barban and Varaždin, are increasingly aware that an event is desirable to the host destination to the degree that it can enhance the destination's brand.

Table 1. Factors affecting positively the success of events in branding destinations

\begin{tabular}{|l|l|}
\hline BARBAN & VARAŽDIN \\
\hline $\begin{array}{l}\text { coordination of event with natural, cultural and tradi- } \\
\text { tional values of tourist destination }\end{array}$ & $\begin{array}{l}\text { coordination of event with physical and communica- } \\
\text { tional infrastructure of tourist destination }\end{array}$ \\
\hline pride of local population and their support for event & pride of local population and their support for event \\
\hline $\begin{array}{l}\text { cooperative work and cooperation of all tourist destina- } \\
\text { tion participants in event creation and implementation }\end{array}$ & $\begin{array}{l}\text { point of differentiation in relation to events in other } \\
\text { tourist destinations }\end{array}$ \\
\hline event media coverage & event media coverage \\
\hline $\begin{array}{l}\text { inclusion of tourist destination name in event title, logo } \\
\text { and/or slogan }\end{array}$ & keeping of event brand "fresh" and relevant \\
\hline
\end{tabular}

Source: results of the author's research 
Events and destinations share the ability to co-brand each other. The research participants have, therefore, identified five key factors, which, according to their experience in event management and subjective opinion, influence the most a successful destination branding as shown in Table I. The obtained results partly coincide with the existing research results, where Jago, Chalip, Brown, Mules \& Ali (2OO2) quote that if the event impacts do not achieve a positive impact, they can have a negative influence on the destination brand.

As for Trka na prstenac, as a Barban brand, it was determined through the interview that Barban already bases its recognisability upon the event, but there remain a string of possibilities on how it can be even further used. It is important that the event is used throughout the year and not only during the few days a year when it is staged. As is evident from Figure 3 , this event has its recognizable logo in which the name of the destination Barban is included. Also, a monography of the race on the occasion of the 3oth anniversary of the revived Trka na prstenac event. Work on the creation of a verbal identity of an event as a brand is also planned in the future. In the use of the event Trka na prstenac in the branding of Barban, only the factor "cooperative work and cooperation of all tourist organization participants in event creation and implementation" was identified as critical, therefore, additional future work is needed on mutual making of developmental decisions by all the subjects who, directly or indirectly, participate in the formation of the Barban tourist offer.

For Špancirfest, as the brand of Varaždin, it is necessary to point out that the event itself is a festival brand which is, considering the number of visitors, tourist traffic and the number of tickets sold, estimated to have a high market value. One of the goals of that brand is also the market positioning of Varaždin as a year-round cultural and tourist destination and the results are already visible. The event logo, in which, just as in the previous case, the tourist destination name is also included, is shown in Fig 3 and the verbal event identity as a brand is designed through the slogan "The festival of good emotions". When using Špancirfest in the branding of Varaždin, the identified critical factors are: "assessment of changes in the profile, attitudes and perceptions by the destination tourists and event visitors" and "continuous monitoring of satisfaction of destination tourists and event visitors" due to the lack of financial means for the relevant research, "long-term event (co-)financing" due to the impossibility of predicting sponsor and donator activities, through which the event is financed and "cooperative work and cooperation of all tourist organization participants in event creation and implementation" due to insufficient partnerships of all the bearers of the Varaždin tourist offer.

The research results indicate that both destinations which are included in the research lack long-term event planning documents. On a yearly basis, Varaždin produces a marketing plan, in which marketing activities relevant to Špancirfest are included, while Barban does not have even such a short-term document of activity implementation. Looking at the
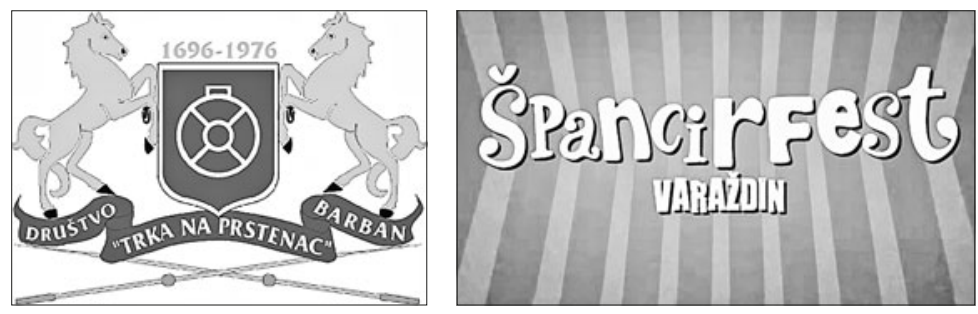

Figure 3. Logos of events "Trka na prstenac" and "Špancirfest"

Source: Tourist Office Barban and City Tourist Association Varaždin 
role of strategic documents from a perspective of destination branding by means of events, their non-existence slows down the advancement of the event itself, but also of the destination, due to the unfamiliarity with the vision and the mission and non-existence of aims and goals for their realization.

\section{Conclusion}

Events and tourist destinations are interlinked. Event brand can influence improvement of the image or building of a destination brand by the transfer of elements of event brand to destination or vice-versa.

The recommendations which impose while writing this research conclusion are the following: in order for the destinations Varaždin and Barban to, in a quality manner, continue with the started process of branding, it is necessary to conduct visitor-oriented research, i.e. research the motives of tourist and visitor arrival. Such research is, otherwise, neglected due to the lack of financial means. Then, based on defining of the main visitors motives and needs, it is necessary to define destination development strategic guidelines and to design event programmes in accordance with those needs. All stakeholders, starting from the citizens to the local authorities need to be involved in the process of defining destination and event goals, as well as in their coordination, in order for the strategy to be in line with the principles of sustainable development. A quality strategic document in which all destination, event and stakeholders' goals are coordinated, represents a link which connects those three key players, thus enabling the transfer of the event branding process to the whole destination i.e. that benefits from branding become mutual. Involving key stakeholders, such as citizens, local authority and investors in the process of adoption of strategic documents, will later serve in the process of branding in the manner that it will ensure their support. It is the lack of support by the local authority, investors and citizens, as well as sponsors itself that is a frequently stated limitation in the process of destination branding by means of events.

Event managers must raise the awareness of the importance of defining of long-term strategic development documents, as the first step in the process of branding which will facilitate quality and focused development towards the desired goals. Destination branding requires involvement of professionals from local authorities and tourist organizations, as well as the support of the local community; this is how their previous involvement in the realization of a long-term destination strategy will make destination branding easier.

\section{References}

Baker, B. (2007). Destination branding for small cities, OR: Creative Leap Books, Portland. Berthon, P., Hulbert, J. M., Pitt, L. F. (1999). Brand Management Prognostications. MIT Sloan Management Review, 4O, 2, 53-65.

Blain, C., Levy, S. E., Ritchie, J. R. B. (2005). Destination Branding: Insights and Practices from Destination Management Organizations. Journal of Travel Research, 43, 328-338.

Bowdin, G., Allen, J., O’Toole, W., Harris, R. \& McDonnell, I. (2006). Event Management, 2nd Edition, Butterworth-Heinemann, Elsevier, Oxford.

Caldwell, N., Freire, J. R. (2OO4). The differences between branding a country, a region and a city: Applying the Brand Box Model. Journal of Brand Management, I2, 5O-6I. 
Carlsen, J., Getz, D., Soutar, G. N. (2000) Event evaluation research. Event Management, $6,3,247-257$.

Chalip, L., Costa, C. A. (2005). Sport Event Tourism and the Destination Brand: Towards a General Theory“. Sport in Society, 8, 2, 2I8-237.

Crompton, J. L., McKay, S. L. (1997). Motives of Visitors Attending Festival Events. Annals of Tourism Research, 24, 2, 425-439.

Derrett, R. (2000). Can Festivals Brand Community Cultural Development and Cultural Tourism Simultaneously?, in Events Beyond 2000: Setting the Agenda, Proceedings, Australian Centre for Event Management, School of Leisure, Sport and Tourism, University of Technology, Sydney, July I5-I6, I2O-I3O.

Derrett, R. (20O2). Making Sense of How Festivals Demonstrate a Community's Sense of Place, in International Event Research Conference: Events and Place Making, Proceedings, Australian Centre for Event Management, Sydney, July I5-I6, 34-59.

Esu, B. B., Mbaze-Arrey, V. (2009). Branding of Cultural Festival as Destination Attraction: A Case Study of Calabar Carnival. International Journal of Business Research, 2, 3, I82-I92.

Fredline, E., Faulkner, B. (2000). Community Perceptions of the Impacts of Events, in Events Beyond 2000: Setting the Agenda, Proceedings, Australian Centre for Event Management, School of Leisure, Sport and Tourism, University of Technology, Sydney, July I5-I6, 60-74.

Fyall, A., \& Garrod, B. (2005). Tourism marketing: A collaborative approach, Clevedon: Channel View Publications.

Getz, D. (2005). Event Management \& Event Tourism, 2nd Edition, Cognizant Communication Corporation, New York.

Getz, D. (2007). Event Studies - Theory, Research and Policy for Planned Events, Butterworth-Heinemann, Elsevier, Oxford.

Getz, D. (2008). Event Tourism: Definition, Evolution, and Research. Tourism Management, 29, 3, 403-428.

Hede, A., Jago, L., Deery, M. (2002). Special Event Research I990-2OOI: Key Trends and Issues, in International Event Research Conference: Events and Place Making, Proceedings, Australian Centre for Event Management, Sydney, July I5-I6, 305-338.

Hong, S. (2OIO). Revitalizing tradition through festivals: the role of tourism in the production of a "traditional" festival, the Tamnaguk Ipchun Gutnori on Jeju, S. Korea, Paper presented at the Global Events Congress IV: Events and Festivals Research: State of the Art, Leeds, UK, July I4-I6.

Jago, L., Chalip, L., Brown, G., Mules, T., Ali, S. (2OO2) The Role of Events in Helping to Brand a Destination, in International Event Research Conference: Events and Place Making, Proceedings, Australian Centre for Event Management, Sydney, July I5-I6, III-I43.

Jago, L., Chalip, L., Brown, G., Mules, T., Ali, S. (2003). Building events into destination branding: insights from experts, Event Management, Vol. 8, 3-I4.

Jayaswal, T. (2009). Events-induced tourism: A protocol analysis, Master's Thesis, Auckland University of Technology.

Johansson, J. (2007). Working with Events to build a Destination Brand Identity - the DMO Perspective, Master's Thesis, School of Business, Economics and Law - Göteborg University.

Križman Pavlović, D. (2008). Tourism Destination Marketing, Mikrorad, Zagreb. (in Croatian) 
Marzano, G., Scott, N. R. (2006). Consistency in Destination Branding: The Impact of Events, Global Events Congress and Event Educators Forum, Brisbane, Australia, 27-29 September, 196-205.

McDonnell, I., Gebhardt, S. (2002). The Relative Effectiveness of Special Events as a Promotional Tool: A Case Study, in International Event Research Conference: Events and Place Making, Proceedings, Australian Centre for Event Management, Sydney, July I5-I6, 389-4I7.

Morrison, A. M., Anderson, D. J. (2002). Destination branding, Paper presented at the Missouri Association of Convention \& Visitor Bureaus Annual Meeting, June IO.

O'Sullivan, D., Pickernell, D., Senyard, J.M. (2009). Public sector evaluation of festivals and special events. Journal of Policy research in Tourism, Leisure and Events, I, I, I9-36.

O'Toole, W.J. (2005). Engineering Events: A Comparison of the standard Project Management Methodology with the Management of Events and Festivals, Master's Thesis, University of Sydney, Australia.

Pike, S. (2004). Destination brand positioning slogans - towards the development of a set of accountability criteria. Acta Turistica, I6, 2, IO2-I24.

Priporas, C.V. (2005). Is It Difficult to Market a City as a Convention Destination. Journal of Convention \& Event Tourism, 7, 2, 87-99.

Quinlan, T. (2008). A Stakeholder Approach to the Branding of Urban Tourism Destinations, Master's Thesis, Waterford Institute of Technology.

Richards, G., Wilson, J. (2OO2). The Use of Cultural Events in City Promotion: Rotterdam Cultural Capital of Europe 200I, in International Event Research Conference: Events and Place Making, Proceedings, Australian Centre for Event Management, Sydney, July I5-I6, 593-627.

Schulenkorf, N. (2OIO). Community Empowerment through Sport and Events: A Conceptual Framework for Sport-for-Development Projects, Paper presented at the Global Events Congress IV: Events and Festivals Research: State of the Art, Leeds, UK, July I4-I6.

Tasci, A. D. A., Kozak, M. (2006). Destination brands vs. destination image - do we know what we mean?. Journal of Vacation Marketing, I2, 4, 299-3I7.

Telišman-Košuta, N. (2OII). Tourism Destination Branding, in: Čorak, S., Challenges of Tourism Management, Institute for Tourism, Zagreb.

Thompson, A. A., Strickland, A. J., Gamble, J. E. (2005). Crafting and Executing Strategy: The quest for competitive advantage, McGraw-Hill, New York.

Wagner, O., Peters, M. (2009). The Development and Communication of Destination Brand Identity - The Case of the Alps, in Tourism Destination Development and Branding, Proceedings, Eilat, Israel, October I4-I7, 2-I8.

Wood, E. (2005). Measuring the economic and social impact of local authority events. The International Journal of Public Sector Management, I8, I, 37-53.

Xing, X., Chalip, L. (2006). Effects of Hosting a Sport Event on Destination Brand: A Test of Co-brending and Match-up Models. Sport Management Review, 9, 49-78.

Yin, R. K. (2003). Case Study Research: Design and Methods, Third Edition, Applied Social Research Methods Series, Vol. 5, Sage Publications, Inc., London. 